\title{
Knjižno in neknjižno na dveh mariborskih radiih v knjigi Alenke Valh Lopert
}

\author{
Melita Zemljak Jontes
}

Cobiss: 1.19

\begin{abstract}
Alenka Valh Lopert, Med knjižnim in neknjižnim na radijskih valovih $v$ Mariboru, Maribor: Študentska založba Litera, 2013, 336 str.
\end{abstract}

Knjiga Med knjižnim in neknjižnim na radijskih valovih v Mariboru predstavlja v slovenskem jezikovnem prostoru eno redkih in zato še posebej dragocenih celostnih znanstvenih analiz in presoj kulture govora na izbranem komercialnem in nacionalnem radiu $\mathrm{V}$ Mariboru. Monografija je logična in pričakovana nadgradnja predhodnega znanstvenega dela s področja govorjene jezikovne kulture s poudarkom na dvojnosti jezikovne norme, tj. neknjižnega pokrajinskega pogovornega jezika Maribora in knjižnega govorjenega jezika, katerega sklepni rezultat je bila knjiga iste avtorice $\mathrm{z}$ naslovom Kultura govora na Radiu Maribor (2005). Vsebina pričujoče monografije je razdeljena na tri temeljna poglavja: uvod s prikazanim predmetom raziskovanja in namenom raziskovalnega dela $\mathrm{s}$ pričakovanimi ugotovitvami, teoretični del s prikazom družbenih in jezikoslovnih vidikov slovenskega jezika, $\mathrm{z}$ opredelitvijo mariborskega neknjižnega pogovornega jezika $v$ okviru socialnih zvrsti jezika in s predstavitvijo radia kot medija, žanrov v medijih in obeh radijskih postaj (Radio Maribor, Radio City), katerih oddaje so služile kot govorno gradivo za jezikoslovno analizo; ključni del monografije predstavlja empirični del s predstavitvijo gradiva, z glasoslovno, oblikoslovno in skladenjsko analizo in analizo besedja ter sredstev govornostične in vplivanjske vloge besedila, tudi v navezavi na spol govorcev. Analiza gradiva prinaša sprotne ugotovitve in komentarje, monografija kot celota pa ključne povzemalne ugotovitve $\mathrm{s}$ širokim izborom domače in tujejezične literature.

Teoretični del monografije sestavlja podpoglavij. Prvo podpoglavje zaradi družbene vloge medijev osvetljuje družbeni vidik slovenskega jezika: jezik in govor, jezik in identiteto, jezik in komunikacijo ter jezik kot prestiž, zanimiv je tudi pregled govora, upoštevajoč spol govorcev. Drugo podpoglavje se osredinja na jezikoslovni vidik slovenskega jezika, in sicer z vidika socialne zvrstnosti slovenskega jezika, razmerja in odnosa med knjižnim ter neknjižnim v slovenskem jeziku, med normo in vsakdanjim govorom, z vidika odnosa med narečjem in knjižnim jezikom, obravnavan je govorjeni jezik kot prenosnik, prikazane so vloge govorjenih besedil, poudarjen pa je tudi pomen aktualnega govornega korpusa slovenščine. V četrtem podpoglavju se avtorica posveča radiu kot mediju (radiu in kulturi govora; okolju in radiu; razlikam med nacionalnim in komercialnim radiem). Peto podpoglavje se 
posveča predstavitvi žanrov $\mathrm{v}$ medijih s poudarkom na (še vedno) nedorečenosti žanrov v govorjenih medijih v primerjavi s pisnimi mediji in žanri.

Uvodna splošnejša teoretična podpoglavja premišljeno dopolnjujeta $\mathrm{v}$ empirično raziskavo usmerjeni podpoglavji, ki obravnavata konkretno jezikovno in medijsko situacijo: tretje podpoglavje prinaša celostni vpogled $\mathrm{v}$ raziskave in ugotovitve raziskav o mariborskem neknjižnem pokrajinskem pogovornem jeziku kot mestni govorici ter ga tako teoretično kot empirično domišljeno postavlja $\mathrm{v}$ okvir slovenskih neknjižnih pokrajinskih pogovornih jezikov, ki so v slovenskem (dialektološkem) jezikoslovnem raziskovanju nujno potrebni večje pozornosti strokovne javnosti in $\mathrm{s}$ tem dokončne umestitve $\mathrm{v}$ jezikovni socialnozvrstni sistem različic govorjenih jezikov, opazovanih ne le z - obvezno - strukturalističnega, temveč tudi $\mathrm{s}$ pragmalingvističnega vidika. $\mathrm{V}$ šestem podpoglavju sta predstavljeni $\mathrm{v}$ analizo zajeti mariborski radijski postaji, tj. Radio Maribor in Radio City.

Empirični del monografije predstavlja dragocene ugotovitve analize oddaj kot študije vzorca nacionalnega (Radia Maribor) in komercialnega radia (Radio City) s skupno 220 minutami posnetega govora (s prevladujočimi govorjenimi in ne branimi besedili), s posnetim celodnevnim programom, z zajemom različnih novinarjev/napovedovalcev/moderatorjev in naključnih nepoklicnih sogovorcev po telefonu ter $\mathrm{z}$ gosti v studiu. Gradivo je zapisano s knjižnimi znaki za fonetični zapis samoglasnikov, le za natančno ponazoritev glasovnih različic je ponekod uporabljen tudi dialektološki način zapisovanja. Razumljivost zapisanega gradiva zaradi približevanja knjižnemu zapisu je ena tistih odlik monografije, ki strogo znanstveno delo približuje širši zainteresirani (ne zgolj strokovni) javnosti, ne nazadnje pa izkazuje prepotrebno uporabnost tudi v formalnem šolskem izobraževalnem sistemu, in to ne le pri pouku slovenščine, temveč omogoča tudi medpredmetna povezovanja.

Natančnejša členitev empiričnega dela monografije prinaša ugotovitve glede na posamezne jezikovne ravnine. Na glasoslovni ravnini kažejo rezultati primerjave analize govora pri poklicnih govorcih na obeh radijskih postajah večjo zgoščenost rabe tipičnih elementov mariborskega pogovornega jezika pri spontanem govoru Radia City v primerjavi z Radiem Maribor (npr. dolgi ozki $o$ za knjižni dolgi široki $o$, izgovor $f$ za nezveneči dvoustnični $v$, umik naglasnega mesta na prvi zlog v besedi, dolgi široki $e$ pred zvočnikom $r$ za ozki knjižni $e$, izgovor fonema $v$ za dvoglasniškfonemsko različico ipd.). Rezultati analize kažejo na večji delež istovrstnih neknjižnih glasoslovnih odmikov pri nepoklicnih govorcih v spontanem govoru v oddajah obeh radijskih postaj, vendar $\mathrm{z}$ večjim razkorakom v oddajah Radia Maribor.

Realizacija tipičnih oblikoslovnih značilnosti pogovornega jezika se je znotraj pregibnih besednih vrst za najpogostejšo izkazala pri pridevniški besedi (npr. določna oblika pridevnika za nedoločno, kazalni zaimek tá za izražanje določnosti pridevnika, kazalni zaimek tóti, tóto za poudarjanje določnosti, kíri za 'kateri', kák za 'kakšen -šna -o', èn, êna, êno za poudarjanje nedoločnosti ipd.; od teh je najpogostejša raba dveh kategorij, èn, êna, êno za izražanje nedoločnosti, in kàr za 'ki'); na Radiu City kar pri polovici poklicnih govorcev pri spontanem govoru, pri nepoklicnih pa zelo redko, medtem ko na Radiu Maribor le pri enem poklicnem 
govorcu (spontani govor) in pri dveh nepoklicnih govorcih; tudi pri glagolu (npr. raba pogovornega nedoločnika, ki ga je na Radiu City slišati pri skoraj vseh poklicnih in nepoklicnih govorcih pri spontanem govoru, na Radiu Maribor pa je tovrstna raba pri poklicnih govorcih pri spontanem govoru zelo redka). Izpostaviti je treba tudi rabo nepolnopomenskih besednih vrst oz. njihovo raznovrstno (neknjižno in knjižno) rabo, ki je v znanstvenih analizah neredko prezrta.

Skladenjska razčlenitev gradiva na nacionalnem Radiu Maribor pri spontanem govoru kaže na prevladovanje zapleteno zloženih povedi, saj je dvogovorom zaradi zahtevnejših tem namenjenega tudi več časa, gradivo Radia City pa pri neposrednem ubesedovanju kaže na prevladovanje enostavčnih ter dvostavčnih povedi. Pogosti so (še posebej na radiu City) vrinjeni stavki, tj. stavki z okrnjeno zgradbo, nedokončani stavki, zamolki, prekrivanja govora, preskoki, izpusti ter ponavljanja besed, besednih zvez, skladenjskih vzorcev, popravljanja ter pojasnjevanja z nestavčnim pojasnilom.

Prevzeto in stilno zaznamovano besedje se pri spontanem govoru na radiu Radiu City in na Radiu Maribor pogosteje pojavlja pri nepklicnih govorcih, in sicer največ iz oziroma prek nemščine, angleščine, srbščine, hrvaščine, češčine, francoščine, praslovanščine, vulgarne latinščine in italijanščine. Pri branju (reproduktivnem govoru) je na obeh radijskih postajah tovrstnega besedja malo.

Pregled frazemov glede na govorce kaže, da poklicni govorci pogosteje uporabljajo frazeme na komercialni radijski postaji v primerjavi z nacionalno radijsko postajo, podobno se kaže tudi pri reproduktivnem govoru (branju).

Za ponazoritev govornostične in vplivanjske vloge medijev je bila izvedena zanimiva raziskava o rabi členkov, ki kaže na vpliv pogovornega jezika na jezik medijev. Avtorica monografije z raziskavo opozarja na problematiko (ne-)obravnave členkov v slovenskem jezikoslovju in poudarja njeno pomembnost.

Izjemno zanimiva je raziskava podobnosti in razlik v pojavljanjih knjižne oz. neknjižne rabe jezika glede na spol govorcev, ki se odraža tudi v jeziku medijev. Ženske se kažejo kot previdnejše, vljudnejše, pozornejše in natančnejše pri izražanju, očitna pa je tudi tradicionalno večja toleranca javnosti do moških. Pri nepoklicnih govorcih je razlik med ženskami in moškimi zelo malo; ob tem prihaja do preklapljanja med socialnimi zvrstmi v smeri knjižne izreke, poklicni govorci pa se od nje na komercialnih radijskih postajah prav zaradi približevanja ciljni publiki hote oddaljujejo.

Monografija Med knjižnim in neknjižnim na radijskih valovih v Mariboru je pomemben prispevek na področju raziskovanja socialne zvrstnosti slovenskega jezika z njegovo funkcijo, ki jo opravlja v medijih. Avtorica s svojo izjemno natančno analizo gradiva in prodornimi ugotovitvami sistematično postavlja ogledalo jeziku v njegovi vsakdanji medijski rabi. Monografija je tako dobrodošel prispevek ne le k natančnim dialektološkim in medijskim ali splošnojezikoslovnim raziskavam jezika geografsko zamejenega območja, ampak prinaša tudi neposreden vpogled v spreminjanje jezikovne norme, po zgledu pričujoče raziskave tudi na drugih geografskih območjih slovenskega jezikovnega prostora. Tovrstne raziskave bi omogočile lažji vpogled v dejansko stanje rabe govorjenega jezika in ne nazadnje stopnje uzaveščenosti govorjene jezikovne kulture. 